\title{
Research Article: Evaluation of pigeonpea var. BSMR 853 under different planting methods to land configuration
}

\author{
R.K. SATHE, B.N. AGLAVE AND V.V. PATIL
}

Article Chronicle : Received : 13.07.2017;

Accepted :

28.07.2017

KeY Words :

Pigeonpea,

Transplanting, Dibbling of seed,

SUMMARY : The field investigation entitled "Evaluation of pigeonpea var. BSMR 853 under different planting methodsto land Configuration" conducted at Department of Agronomy, Vilasrao Deshmukh College of Agricultural Biotechonology, Latur. The soil was clayey in texture, moderate in available nitrogen, low in available phosphorus, high in available potassium and moderately alkaline in reaction. The environnemental conditions prevailed during expérimental period was not so favorable. The experiment was laid out in Factorial RBD with three replication and 24 plot, the gross and net plot size of each experimental unit was : $6.30 \times 4.20 \mathrm{~m}^{2}$ and $4.50 \times 3.60 \mathrm{~m}^{2}$, respectively . The treatments were two land configuration Flat bed and ridges and furrows treatments with Dibbling of seeds and Transplanting of seedlings. The sowing was done in polythene bag on $25^{\text {th }}$ June 2014 by dibbling and transplanting done on $25^{\text {th }}$ July 2014. Transplanted pigeonpea at ridges and furrows was significantly higher grain yield $\left(1937 \mathrm{~kg} \mathrm{ha}^{-1}\right)$ is found beneficial in improving growth characters, yield attributes and yield over all of the treatment. Lowest seed yield was recorded by treatmentof dibbled pigeonpea at flat beds $\left(1674 \mathrm{~kg} \mathrm{ha}^{-1}\right)$, The B: C ratio was maximum with Treatments at ridges and furrows.

Land configuration, Economics

How to cite this article : Sathe, R.K., Aglave, B.N. and Patil , V.V. (2017). Evaluation of pigeonpea var. BSMR 853 under different planting methods to land configuration. Agric. Update, 12(TECHSEAR-3) : 853-856; DOI: 10.15740/HAS/AU/12.TECHSEAR(3)2017/853-856. 